\title{
Analysis on Environmental Information Disclosure of Listed Companies in Heavy Pollution Industries in Shandong Province
}

\author{
Xuan Wang \\ Shandong Women's University,Shandong, Jinan 250300, China.
}

\begin{abstract}
Based on the research samples of Listed Companies in heavy pollution industries in Shandong Province, this paper studies the current situation of their environmental information disclosure, finds out the problems existing in the environmental information disclosure of such companies, analyzes the causes of the problems from different levels, and finally puts forward countermeasures and suggestions to improve the environmental information disclosure of Listed Companies in heavy pollution industries, in order to provide some reference for improving the level and quality of environmental information disclosure of Listed Companies in heavy pollution industry.
\end{abstract}

Keywords: Heavy pollution industry; Environmental information disclosure; Stakeholders

\section{Raising of the problem}

The development of human society is inseparable from the environment. The environmental problem is an eternal topic that human beings, countries, enterprises and even individuals must face. The Chinese government takes "innovative development, coordinated development, green development, open development and shared development" as its future development strategy, among which "green development" is the latest highlight. A series of principles and policies show that economic development and environmental development are inseparable. If an enterprise has a foothold in the future development, it must abide by the laws of nature and take the road of sustainable development of economy, society and environment. For heavy polluting industries, due to the particularity of their own industries, enterprises should pay more attention to the economic benefits brought by the environment in the process of their own operation, and listed companies should pay more attention to their environmental information disclosure.

As a resource rich province, Shandong's GDP is in the forefront of the country. In recent years, new progress has been made in the conversion project between new and old kinetic energy. The backward and inefficient production capacity polluting industries such as steel, coal, etc. have accelerated their withdrawal, making room for advanced production capacity. However, we should also realize that the proportion of heavy chemical industry in the province is still too high, and the pressure to resolve excess capacity still exists. For listed companies in the province, enterprises should pay more attention to social responsibility while creating their own value. As a responsible subject, how to play its due role in the coordinated development of enterprises, economy and environment is a topic that heavy pollution industry enterprises should pay attention to. Therefore, enterprises should publicize their efforts in environmental protection, implementation of environmental responsibility, environmental investment and Realization of environmental objectives. In recent years, the state has issued a series of regulatory documents to require enterprises in heavy pollution industries to regularly disclose their environmental information on environmental pollution and environmental protection. As the main body of disclosure, enterprises disclose relevant environmental information in their annual financial and accounting reports, but there are some problems in the content, method and form of disclosure. This paper selects listed companies in heavy pollution industries in Shandong Province as the research sample, based on the relevant data of environmental information disclosure of enterprises in different industries in 2017, analyzes the problems and reasons in various aspects of environmental information disclosure, and then puts forward countermeasures and suggestions.

\section{Problems of environmental information disclosure of Listed Companies in heavy pollution industries in Shandong Province}

Based on the relevant data from www.cninfo.com and excluding companies with incomplete data, ST and *ST, this paper selects a total of 27 companies as the research objects. Through sorting and summarization, problems in the information disclosure of listed companies in heavy pollution industries are found.

\subsection{The way of disclosure is not uniform}

In terms of the disclosure of environmental information, this paper sorts out the public announcements of listed companies, mainly from the annual reports of listed companies, social responsibility reports and environmental related announcements.

\section{Copyright (C) 2020 Xuan Wang}

doi: 10.18282/l-e.v9i4.1702

This is an open-access article distributed under the terms of the Creative Commons Attribution Non-Commercial License (http://creativecommons.org/licenses/by-nc/4.0/), which permits unrestricted non-commercial use, distribution, and reproduction in any medium, provided the original work is properly cited. 
It is found that among the listed companies in heavy pollution industry, 21 companies choose to disclose environmental information through annual report, accounting for $77.78 \%, 8$ companies disclose environmental information through social responsibility report, accounting for $29.63 \%$, and 5 companies disclose environmental information through environmental announcement, accounting for $18.52 \%$.It is not difficult to find that most of the listed companies tend to disclose environmental information in the notes to the annual report, but few companies disclose environmental information in other carriers such as social responsibility reports or environmental related announcements. According to the guidelines for environmental information disclosure of listed companies, companies should issue annual environmental reports and regularly disclose environmental information, but from the perspective of disclosure, there are few annual environmental reports.

\subsection{Incomplete disclosure}

In terms of disclosure content, because the company does not reach a unified way of disclosure, but they are all disclosed in the annual financial and accounting report. Therefore, this paper analyzes the environmental information disclosed in the notes to the annual report of listed companies. It is found that among the listed companies in heavy pollution industry, 20 companies choose to disclose pollution information, accounting for $74.07 \%, 16$ companies choose to disclose the construction and operation of pollution prevention and control facilities, accounting for 59.26\%, 9 companies choose to disclose the environmental impact assessment of construction projects and other environmental protection administrative licensing, accounting for 33.33\% There were 10 enterprises that disclosed emergency plans, accounting for $37.04 \%$. According to the contents of environmental information disclosed in the notes to the annual report, the disclosure of enterprises is not comprehensive, especially the disclosure of environmental impact assessment of construction projects and other environmental protection administrative licensing, accounting for only $33.33 \%$, and a few enterprises have not disclosed the above information. Incomplete disclosure may lead to information users unable to obtain comprehensive and high-quality environmental information and affect their decision-making.

\subsection{The form of disclosure is slightly single}

Qualitative information disclosure, quantitative information disclosure and the combination of qualitative and quantitative information are the three main forms of environmental information disclosure of enterprises in heavy pollution industries. According to the statistics of emission information disclosure forms, only 14 enterprises use the combination of qualitative and quantitative information to disclose, while the rest enterprises still mainly use the form of qualitative information disclosure. Similarly, for other information such as the construction and operation of pollution prevention and control facilities, the disclosure form of qualitative information is mainly used, and there is little quantitative information disclosure. Obviously, the form of environmental information disclosure is a little single.

\subsection{Disclosure of differences between industries}

Based on the 16 categories of heavy pollution industries, this paper selects samples and finds that there are differences in the disclosure among the secondary industries in heavy pollution industries. For the listed companies in heavy pollution industries in Shandong Province, the differences of enterprise environmental information disclosure in individual industries are small, but for most other industries, there are still some differences.

\section{The reasons for the problems of environmental information disclosure of Listed Companies in heavy pollution industries in Shandong Province}

\subsection{Internal level}

For the listed companies in heavy pollution industry, although they disclose according to the guidelines issued by government departments, it is still a mere formality, and there is no unified disclosure standard or legal norms when the companies disclose, which leads to that the enterprises tend to disclose more positive or good news when they disclose, while only briefly disclose the information about environmental punishment, which shows that the enterprises are not willing to disclose the positive or good news The management still does not pay enough attention to environmental information disclosure, and the disclosure cost of environmental protection is low.

\subsection{External level}

Although there are disclosure guidelines and other relevant documents as the basis for environmental information disclosure, the environmental protection laws and regulations related to the information disclosure of heavy pollution industries, especially for a specific industry, are not perfect, and a series of supporting legal systems are still needed to regulate the environmental information disclosure. In addition, the government's supervision and guidance on non-standard disclosure need to be further strengthened. Only when the rewards and punishments are reasonable, enterprises will be more active in information disclosure. Finally, the public's attention also affects the level of environmental information disclosure. Although the public's awareness of the environment has improved to a certain extent, the supervision of environmental violations and unreasonable disclosure still needs to be strengthened.

\section{Suggestions on improving the environmental information disclosure of Listed Companies in heavy pollution industries in Shandong Province}

\subsection{Internal level}

For enterprises, first of all, we should formulate a series of environmental protection and environmental information disclosure system suitable for enterprises according to the relevant national laws and regulations, and implement the system to every department and every employee, and take the environmental protection index as the quantitative standard for assessment. 
Secondly, enterprises should attach great importance to environmental information disclosure, from the management level to the employees, they should actively pay attention to the latest environmental protection policies, and at the same time, they should give more suggestions and suggestions for the environmental management of enterprises, so as to form a situation of environmental protection for all employees. Finally, in the specific disclosure, the content of environmental information disclosure should be comprehensive and objective. In addition to the disclosure in the annual financial report of enterprises, the environmental report and other announcements should be regularly disclosed, and the qualitative and quantitative information should be combined.

\subsection{External level}

First of all, the government can continue to improve the environmental protection related laws and regulations and relevant standards, and regulate the environmental information disclosure of a specific industry, so as to make the environmental information disclosure become the norm. Secondly, we should continue to strengthen the supervision of environmental protection and environmental information disclosure. In addition to government supervision, we can also introduce a third party to supervise and evaluate the environmental information disclosure of enterprises, and the introduction of third party supervision can avoid the risk caused by information asymmetry, restrict the environmental information disclosure of Companies, and provide guarantee for environmental information users to make decisions. Finally, the public can participate in the supervision of environmental information disclosure to form a new supervision barrier, so that the company can take more initiative to bear the responsibility of environmental protection, further enhance the awareness of environmental protection, fulfill the obligation of environmental protection, and improve the level and quality of environmental information disclosure.

In a word, in order to solve the problems of environmental information disclosure of Listed Companies in heavy pollution industry, the internal level should formulate environmental protection related system, all staff should protect the environment, the information disclosure content is comprehensive, the way is unified, and the form is more abundant. At the external level, relevant laws and regulations should be improved, and the third party and public supervision should be introduced. Only by forming internal and external forces can the level of environmental information disclosure be further improved and the coordinated development of enterprise economy and environment be realized.

\section{References:}

[1]Yan Benzong, Wang Jianming, Luying.An Empirical Analysis on environmental information disclosure of Listed Companies in Chinese Biomedical industry[J]. Commercial economy. 2007,6:105-108.

[2]Zhou Yarong, Zhang Lifang, Dongyan. Current situation and Enlightenment of environmental accounting information disclosure[J]. Communication of Finance and Accounting. 2016,34:28-31.

[3]Yao Cuihong, Yu Hong. Analysis of environmental information disclosure of Listed Companies in heavy pollution industry[J]. Commercial Accounting. 2017,5:48-52. 